\title{
Intra- and interspecific morphological variation in sympatric and allopatric populations of Mustela putorius and M. eversmanii (Carnivora: Mustelidae) and detection of potential hybrids
}

\author{
Tamás Cserkész $^{1}$ (D) Csaba Kiss $^{2} \cdot$ Zoltán Barkaszi $^{3}$ (D) $\cdot$ Tamás Görföl $^{1,4}$ (D) Igor Zagorodniuk $^{3}$ (D) $\cdot$ Gábor Sramkó $^{5}$ (D) \\ Gábor Csorba ${ }^{1}$ (i)
}

Received: 1 July 2020 / Accepted: 16 October 2020 / Published online: 26 October 2020

(C) The Author(s) 2020

\begin{abstract}
European mustelids include the European polecat, Mustela putorius, and the steppe polecat, M. eversmanii. Both occur sympatrically in the Pannonian Basin, where M. eversmanii hungarica represents the westernmost part of the latter species and they allegedly hybridize. We investigated the morphological relationships in sympatric and allopatric populations of these mustelids with representative sampling, taxonomic and geographic coverage. We evaluated inter- and intraspecific patterns of morphological differentiation of 20 cranial measurements and four external traits by distance-based morphometric approaches and multivariate analyses. Our results revealed a considerable heterogeneity in cranial morphology. The two species appeared to be clearly differentiated although sympatric populations were closer to each other and had a slight overlap in the morphometric space. Within M. eversmanii, the subspecies and the nominal taxon only partially overlapped, and $M$. eversmanii eversmanii was more distant from M. putorius than subspecies hungarica. Although morphometric analyses revealed several intermediate individuals in size in sympatric M. eversmanii and M. putorius populations, only a small fraction of such specimens showed conflict in discrete morphological characters with the diagnostic discriminant function. We interpret these results as an indication of ongoing hybridisation between sympatric populations, but the low number of hybrids identified suggests limited genetic exchange between the species.
\end{abstract}

Keywords Polecats $\cdot$ Ferrets $\cdot$ Morphometry $\cdot$ Phenotype $\cdot$ Hybridisation

Communicated by: Andrzej Zalewski

Electronic supplementary material The online version of this article (https://doi.org/10.1007/s13364-020-00543-6) contains supplementary material, which is available to authorized users.

Tamás Cserkész

cserkesz.tamas@nhmus.hu

1 Department of Zoology, Hungarian Natural History Museum, H-1088, Baross u. 13, Budapest, Hungary

2 Department of Systematic Zoology and Ecology, Eötvös Loránd University, Institute of Biology, Pázmány Péter sétány 1/c., H-1117, Budapest, Hungary

3 National Museum of Natural History NAS of Ukraine, 15 Bohdan Khmelnytsky St., Kyiv 01030, Ukraine

4 National Laboratory of Virology, Szentágothai Research Centre, University of Pécs, Ifjúság útja 20, H-7624 Pécs, Hungary

5 MTA-DE 'Lendület' Evolutionary Phylogenomics Research Group, H-4032 Egyetem ter 1, Debrecen, Hungary

\section{Introduction}

Three extant polecat species of the subgenus Putorius are recognized: the European polecat (Mustela putorius L., 1758), the steppe polecat (M. eversmanii Lesson, 1827) and the black-footed ferret (M. nigripes (Audubon et Bachman, 1851)). They form the most clearly defined species group of the genus Mustela (Abramov 2000). M. putorius occurs throughout most of Europe from the Great Britain to the Ural Mountains (Croose et al. 2018) with an unclear eastern border in the European forest-steppe zone (see Fig. 1). $M$. eversmanii is distributed from the southern regions of central and eastern Europe, throughout southern Russia (including southern Siberia) and Middle Asia to Mongolia and northern and western China (Heptner et al. 1967). The eastern part of the distribution range of European polecat lies within the range of $M$. eversmanii. The once widespread $M$. nigripes exists in a few remaining populations in North America 


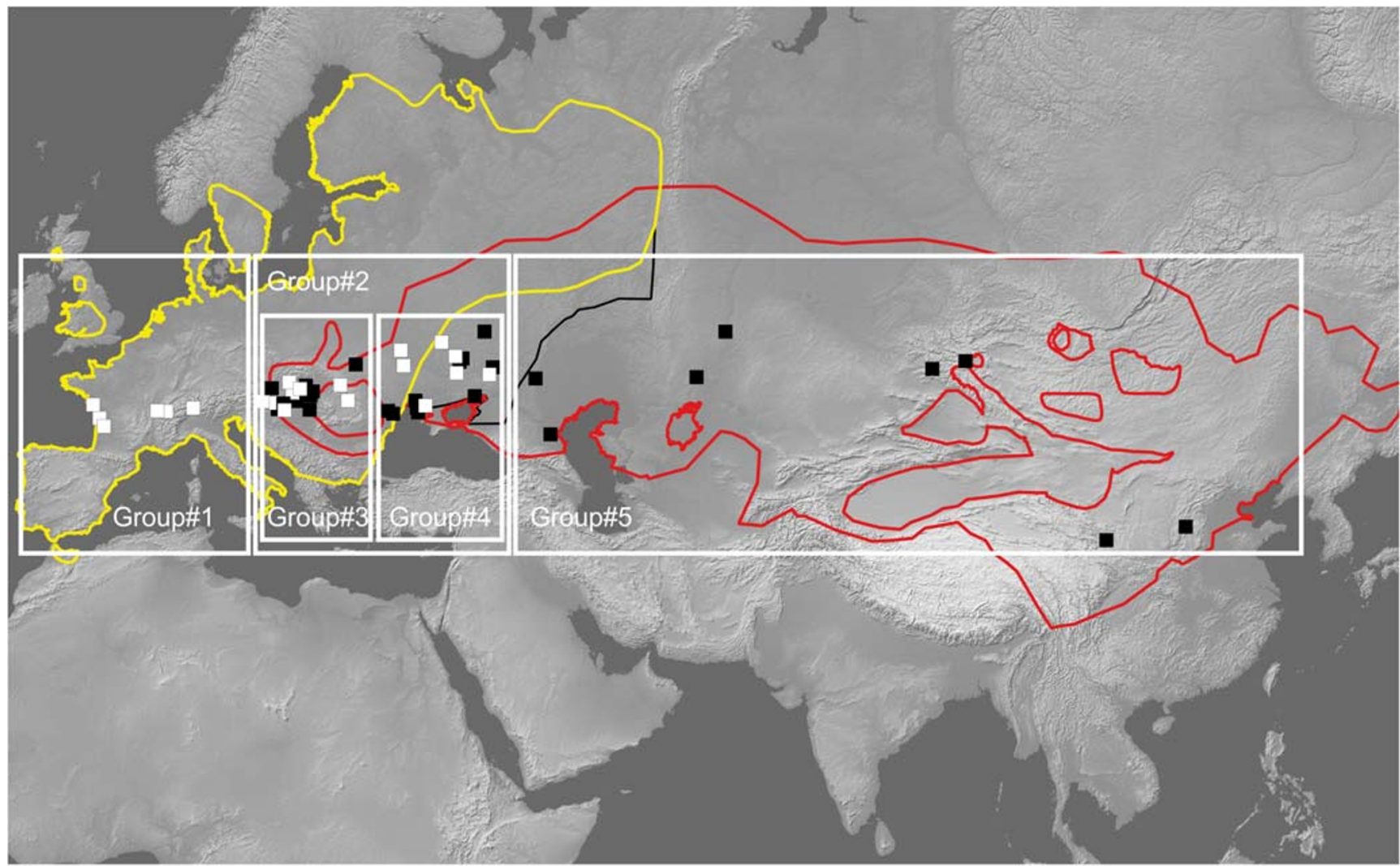

Fig. 1 Geographic origin of the samples studied. Points may correspond to geographically very close localities (black squares $=M$. eversmanii, white squares $=M$. putorius). Distribution range of $M$. eversmanii (red line) has been drawn according to IUCN Red List assessment (Maran et al. 2016) and of the M. putorius (yellow line) according to the IUCN Red List assessment (Skumatov et al. 2016) and Heptner at el. 1967 (complementary black line). According to IUCN Red List assessment, the eastern boundary of the M. putorius lies in the centre of Ukraine, but museum data indicate that the species was spreading further in the east than IUCN indicated, so the map published by Heptner et al. (1967) may be more relevant
(Matchett 2016). The domestic ferret (Mustela furo or M. putorius furo), generally thought to be domesticated from M. putorius (see, e.g. Sato et al. 2003), was bred in captivity as early as the fourth century BC and was introduced to many parts of the world (Nowak and Paradiso 1983).

Generally, polecats are characterized by a remarkable variability in size both between and within sexes (Buchalczyk and Ruprecht 1977). This sexual size dimorphism (SSD) is more pronounced in European polecat than in steppe polecat (Abramov et al. 2016b); however, the average male-biased SSD in both polecat species lies within the range that of other small mustelids. The amplitude of intraspecific variation of values of the steppe polecat is very large and, in general, is larger than in M. putorius. The skull of M. eversmanii is more massive than that of $M$. putorius and represents a further step of specialization towards carnivory as compared to M. putorius (Heptner 1964). Although morphologic and genetic geographical variation of $M$. putorius was examined in more detail (Buchalczyk and Ruprecht 1977; De Marinis 1995; Lawes and Andrews 1987), M. eversmanii has been remained poorly studied so far. A remarkable exception is the study of Abramov et al. (2016a) who examined craniometrics of $M$. putorius and $M$. eversmanii using multivariate statistics with $M$. eversmanii sampled from a narrow geographic range (i.e. specimens were collected exclusively in the central part of the Baraba forest-steppe, Novosibirsk Region, Russia). Wolsan (1993a, b) performed the most extensive and complete morphological study of $M$. putorius and $M$. eversmanii; so far, however, multivariate statistical analysis was not performed on that dataset. Wolsan (1993a, b) also studied morphological introgression between the two European polecat species and provided important results in support of the introgression.

Although several subspecies of $M$. eversmanii have been described-Wilson and Reeder (2005) mentioned six of them-morphological studies have not confirmed the presence of more than two (Wolsan 1993b): M. eversmanii eversmanii and M. eversmanii hungarica Éhik 1928. Wolsan (1993b) described clear morphological differences between the two subspecies: M. eversmanii hungarica populations are characterized by $\geq 50 \%$ proportion of two-rooted P2 and a relatively large M1, in contrast to the nominal form 
where the proportion of two-rooted $\mathrm{P} 2$ is much less than $50 \%$, and $\mathrm{M} 1$ is relatively small. The distribution range of $M . e$. hungarica covers the Pannonian Basin (shared by SE part of the Czech Republic, SW Ukraine, E Austria, Hungary, N Serbia, S Slovakia and W Romania); the European range of M. e. eversmanii includes NE Bulgaria, SE Romania, SE Poland, Moldova, Ukraine east of the Carpathians, southern European Russia and European part of Kazakhstan (the Asian range was reviewed by Maran et al. (2016)). Of the traditionally proposed 12 subspecies of M. putorius, Wolsan (1993b) accepted only two: M. putorius putorius and M. putorius furo. Wilson and Reeder (2005) named seven, but Lariviere and Jennings (2009) - in contrast - mentioned the existence of 22 subspecies (without listing them); thus, the subgeneric classification is quite unexplored in the European polecat, so a review of geographical variation and an integrative taxonomic revision based on novel and detailed morphologic and genetic studies for both $M$. putorius and M. eversmanii is timely.

According to Heptner (1964), hybridization of polecats was not rare on the territory of the former Soviet Union; even the trappers had an own term, "Polecat Tumak" for the hybrids. However, hybridisation was assessed to be of far lesser magnitude than one might expect from their sympatry and close systematic proximity (Heptner et al. 1967). Hybrids were reported from several regions in Eastern Europe: in the forest-steppe zone of Ukraine, in Kursk and Voronezh Regions of SW Russia and in the Trans-Carpathians (i.e. SW Ukraine in the Pannonian Basin). However, in spite of occasional reports of hybrid specimens, hybrid swarms are not observed, and a zone of transgression between the two species is apparently absent (Heptner et al. 1967; Tatarinov 1956). Other reports (Polushina 1958; Zagorodniuk 2011) did not approve the presence of hybrids between the Ukrainian polecats, but detailed studies on this particular question are missing so far. Nevertheless, detecting animal hybrids from external morphology is a remarkably difficult task (e.g. Rees et al. 2003). It is also emerging that gene exchange (hybridisation and introgression) among animal species has been more common than previously believed, and its frequency has been underestimated in the past (Abbott et al. 2013). Hybrids of M. eversmanii and $M$. sibirica, M. putorius and M. sibirica or M. lutreola and M. putorius are also known to exist (Abramov 2000; Heptner et al. 1967; Ternovsky and Ternovskaya 1994), but occurrence of hybrids in natural population is not reported. Cabria et al. (2011) suggested that hybridisation and genetic introgression between the endangered $M$. lutreola and the more abundant $M$. putorius should be considered a rather uncommon event.

Our knowledge on the phylogenetic relationships between species of polecats is growing; however, the relationships among major geographical populations are quite unexplored. Davison et al. (1999) and Kurose et al. (2008) investigated the
mtDNA phylogeny of mustelids, and the results suggest that both polecats and the European mink either recently speciated or gene flow through hybridisation has prevented haplotype divergence, resulting in an unresolved molecular phylogeny. Moreover, molecular analyses could not still answer the question whether ferrets were originally domesticated from M. putorius and/or M. eversmanii. The genetic differentiation was the same as the level of intraspecific variations of other mustelids. M. eversmanii likely diverged from $M$. putorius approximately 1.5 million years ago based on the nuclear DNA region inter-receptor binding protein (IRBP), though cytochrome $\mathrm{b}(C y t B)$ transversions indicate a younger date of 430,000 years (Sato et al. 2003). Since these species are occasionally reported to hybridize where they have an overlap in their distribution, the reality of a true species split has been debated (Blandford 1987), and some authors have also considered if M. putorius, M. eversmanii and M. nigripes could be viewed as a single Holarctic species (Anderson 1977; Anderson et al. 1986; O'Brien et al. 1989). More recently, the phylogenetic relationships between the extant species of polecats (including M. furo) were fully resolved (Wolsan and Sato 2010; Sato et al. 2012). M. furo was more closely related to M. putorius than to M. eversmanii, and interestingly, both parsimony and Bayesian analyses of Wolsan and Sato (2010) recovered $M$. nigripes as basal to a clade containing M. putorius, M. eversmanii and M. lutreola.

We aimed in this study to identify the patterns of morphological differentiation associated with both sympatric and nonsympatric populations of $M$. eversmanii and M. putorius using distance-based ('traditional') morphometric approaches and multivariate analysis. We sampled intact adult specimens to investigate (1) differences among sympatric and nonsympatric populations of $M$. eversmanii and $M$. putorius; (2) intraspecific variation in cranial size between $M$. eversmanii hungarica and M. eversmanii eversmanii; and (3) the presence of potential interspecific hybrid individuals. The present study is the first multivariate analysis which includes specimens from the western range of the steppe polecat (including the poorly studied subspecies $M$. eversmanii hungarica) examining not only the cranial measurements but also the geographical distribution and frequency of the external features described by Pocock (1932) and Wolsan (1993b).

\section{Materials and methods}

The sample set analysed consisted of 273 specimens representing almost the full latitudinal range of $M$. putorius and $M$. eversmanii kept in the scientific collections of the Hungarian Natural History Museum, Budapest (HNHM), National Museum of Natural History at the National Academy of Sciences of Ukraine, Kyiv (NMNHU), National Museum of Natural History; Smithsonian Institution; 
Washington, DC, (USNM), and the Natural History Museum of Geneva (MHNG) (see Table 1 and S1 for collection numbers). Out of these, 178 samples were complete skulls, so they were suitable for taking the measurements. The rest of the samples were checked for external phenotypic characteristics only. As some character states in juvenile specimens may be common to both species (Ansorge and Suchentrunk 2001), only fully grown specimens (judged from the completeness of ossification of skull bones) were used, and juveniles were excluded from all analyses. Specimens were identified by the museum catalogues and cranial identification keys for mustelids (Heptner et al. 1967; Ujhelyi 1994; Wolsan 1993b).

On the basis of the postulated geographical ranges of traditionally recognized species and subspecies, specimens were divided a priori into six geographical groups:

(1) Allopatric putorius group (MP ALLO)

(2) Sympatric putorius group (MP SYM)

(3) (2a) Sympatric putorius group of samples collected east of the Carpathians in Ukraine (MP SYM UKR) - division made only in the analysis of external phenotypical characters

(4) Sympatric eversmanii group including subspecies M. eversmanii hungarica (MEH SYM)

(5) Sympatric eversmanii group including subspecies M. eversmanii eversmanii (MEE SYM)

(6) Allopatric eversmanii group including $M$. eversmanii eversmanii (MEE ALLO)

The American mink (Neovison vison) served as a comparative outgroup (NV). Because of sample sizes and missing values, LDA between sexes was conducted separately only for the MP SYM, MEH SYM and MEE SYM samples.

\section{External phenotypic characteristics}

We paid special attention to external cranial morphological characters as these are described as species-specific characters distinguishing between the two European mustelids by Pocock (1932) and Wolsan (1993b). The following such traits are examined on skulls of the 229 studied specimens (Table 1):

' $A$ ' - height of nasal cavity exceeds its width in M. putorius, whereas it is approximately the same in M. eversmanii.

' $\mathrm{B}$ '- nasal bone is triangular in M. putorius, whereas it is elongated bell or calyx shaped in M. eversmanii.

' C'-postorbital constriction almost straight in M. putorius, in contrast, it has a distinct 'waist' in M. eversmanii.

' $\mathrm{D}$ '- degree of curvature of the hamular process of the internal pterygoid which is only slightly bent posteriorly in eversmanii, but strongly hooked at the tip in the putorius.

We examined the frequency of individuals carrying atypical external phenotypic characteristics or the mixture of the species-specific characteristics in each population and analysed the positions of these atypical samples within the morphological space. The conflict between size and phenotype could be a strong indication of hybridisation, so we match the size and phenotype in several putative hybrids.

\section{Measurements}

Measurements were taken following the definition and numbering of Abramov and Puzachenko (2009): 1, condylobasal length $(\mathrm{CbL}) ; 5$, palatal length $(\mathrm{PL}) ; 6$, maxillary tooth-row
Table 1 The sample size of the different groups considered in this study

\begin{tabular}{|c|c|c|c|c|c|}
\hline \# & Group & $\begin{array}{l}\text { Sample size of } \\
\text { morphometric } \\
\text { analysis }\end{array}$ & $\begin{array}{l}\text { Sample size of } \\
\text { phenotype } \\
\text { characterization }\end{array}$ & Country of origin & Collection \\
\hline 1 & MP ALLO & 25 & 24 & $\begin{array}{l}\text { France and } \\
\text { Switzerland }\end{array}$ & MHNG \\
\hline 2 & MP SYM & 40 & 74 & $\begin{array}{l}\text { Ukraine, Hungary, } \\
\text { Romania and } \\
\text { Slovakia }\end{array}$ & $\begin{array}{l}\text { HNHM, } \\
\text { NMNHU }\end{array}$ \\
\hline 3 & MEH SYM & 51 & 47 & Hungary & HNHM \\
\hline 4 & MEE SYM & 41 & 74 & Ukraine and Russia & $\begin{array}{l}\text { HNHM, } \\
\text { NMNHU }\end{array}$ \\
\hline 5 & MEE ALLO & 10 & 10 & $\begin{array}{l}\text { Russia, Kazakhstan } \\
\text { and China }\end{array}$ & $\begin{array}{l}\text { USNM, } \\
\text { NMNHU, } \\
\text { HNHM }\end{array}$ \\
\hline 6 & N. vison & 11 & - & $\begin{array}{l}\text { Captive-bred and } \\
\text { Canada }\end{array}$ & HNHM \\
\hline
\end{tabular}

For the abbreviations of group names consult main text. Collection numbers and capture locations for specimens analysed can be found in Table S1 Supplementary \#1 
length (MxtL); 7, upper carnassial tooth Pm4 length (PM4L); 8 , length of the auditory bulla (AbL); 9, greatest length between oral border of the auditory bulla and aboral border of the occipital condyles (BcL); 10, zygomatic width (ZyW); 11, mastoid width of skull (MW); 12, postorbital width (PoW); 13, interorbital width (IW); 14, width of rostrum (RW); 15, greatest palatal width $(\mathrm{GpW}) ; 16$, width of the auditory bulla (AbW); 17, width of upper molar M1 (M1W); 18, cranial height $(\mathrm{CH}) ; 19$, total length of the mandible (ML); 20, length between the angular process and infradentale (AL); 21, mandibular tooth-row length (MatL); 22, length of lower carnassial tooth M1 (M1L); and 23, height of mandible in the vertical ramus (MaH). All measurements were taken by the same person (Csaba Kiss) using Mitutoyo digital calliper connected to a notebook.

\section{Statistical analysis}

The normality of data distribution and the homogeneity of the variances were tested by Shapiro-Wilk test, respectively. Because no substantial departures from normality was found within the samples (all $p>0.05$ ), a two-way multivariate analysis of variance (MANOVA) was performed to evaluate variation across the variables in relation to groups. The significance level was set at $p<0.05$. Linear discriminant analysis (LDA) was carried out on the variables to estimate the percentage of correctly classified specimens into each group. Because of sample sizes and missing values, LDA between sexes was conducted separately only for the MP SYM, MEH SYM and MEE SYM samples. The jack-knife procedure was used to avoid the risk of overfitting of data. Matrix of Squared Mahalanobis distances among groups, as obtained in LDA, was compared to the morphometric D2distance matrix. Unweighted pair group method with arithmetic mean (UPGMA) was used to make a distance-based tree to visualize phenetic relationships using distance matrix derived from morphometric measurements. Pairwise comparisons through Student's $t$ test were conducted on the morphological traits among the subspecies of $M$. eversmanii and M. putorius for characters showing the largest differences among groups. All statistical analyses were conducted using STATISTICA ver. 8.0 (STATSOFT 2007) and PAST v3 (Hammer et al. 2001).

\section{Results}

\section{External morphology: phenotypical variability}

The two species show clear morphometric differences in cranial morphology (Fig. 2). We determined the frequency of samples exhibiting the species-specific traits of the other species (Tables 2 and 3). Samples from allopatric populations had species-specific characteristics, whereas $0-8.5 \%$ of the samples exhibited the traits of the other species in sympatric populations. This rate was substantially higher in the group of the $M$. putorius samples from Ukraine, where the ' $\mathrm{B}$ ' and ' $\mathrm{C}$ ' characteristics were atypical in 15.4 and $23.1 \%$, while the ' $\mathrm{A}$ ' characteristics in $38.5 \%$; however, the sample size was quite small. Due to the relatively high number of atypical samples in more groups, we could assume that the rate of misidentified samples could be high. To exclude this possibility, we evaluated the datasets with multivariate analysis.

\section{Craniometrics}

MANOVA indicated a significant difference in size among the populations $(\mathrm{F}=9.8, p<0.0001)$. Mahalanobis distances and F-statistics computed from canonical variate scores on the subset of 20 variables indicated that $M$. putorius populations were significantly different from all other populations. The relationships among all involved populations were summarized on an UPGMA dendrogram derived from Mahalanobis distances on a sample set including Neovison vison (Fig. 3). Based on the UPGMA dendrogram, the samples were arranged in two main clusters with both of them supported by high bootstrap values: (1) M. putorius, without observable inner structures, and (2) M. eversmanii eversmanii + M. eversmanii hungarica. The samples of the eversmanii group were also arranged in two clusters supported by strong bootstrap (bs) score ( $\mathrm{bs} \geq 83 \%$ ). The Mahalanobis distance between the sympatric, same sex M. putorius and $M$. eversmanii hungarica groups was considerably smaller (female: 5.9; male: 7.9) than the distance between sympatric, same sex M. putorius and M. eversmanii eversmanii (female, 11.0; male, 15.1) groups. The greatest distance was found between the geographically most remote Asian M. eversmanii (MEE ALLO) and M. putorius (16.8-20.5). The eversmanii groups of the same sex but different subspecies were also located at small distances (female, 4.9; male, 6.0), and these distances were smaller than the distances between sexes within taxa (MEE SYM, 6.8; MEH, 8.4; MP SYM, 9.3). The smallest distance was indicated between M. eversmanii hungarica and M. eversmanii eversmanii; although it is worth noting that the difference was also significant between these groups, but their data clouds overlapped partly in the morphometric space. The distance between the female groups was always smaller than among the male groups.

\section{Linear discriminant analysis}

Craniometric dataset was also used in discriminant analysis, which strongly supports MANOVA's results. Allopatric groups did not overlap in the morphological space (Figs. 4), but sympatric groups were much closer to each other and displayed a slight overlap. Quite notably, the groups of the 
Fig. 2 Species-specific cranial characters distinguishing between the two European mustelids after Wolsan (1993b): 'A', nasal cavity; 'B', nasal bone; 'C', postorbital constriction; ' $\mathrm{D}$ ', degree of curvature of the hamular process of the internal pterygoid. Part of this figure is taken from Wolsan (1993b: fig. 208)

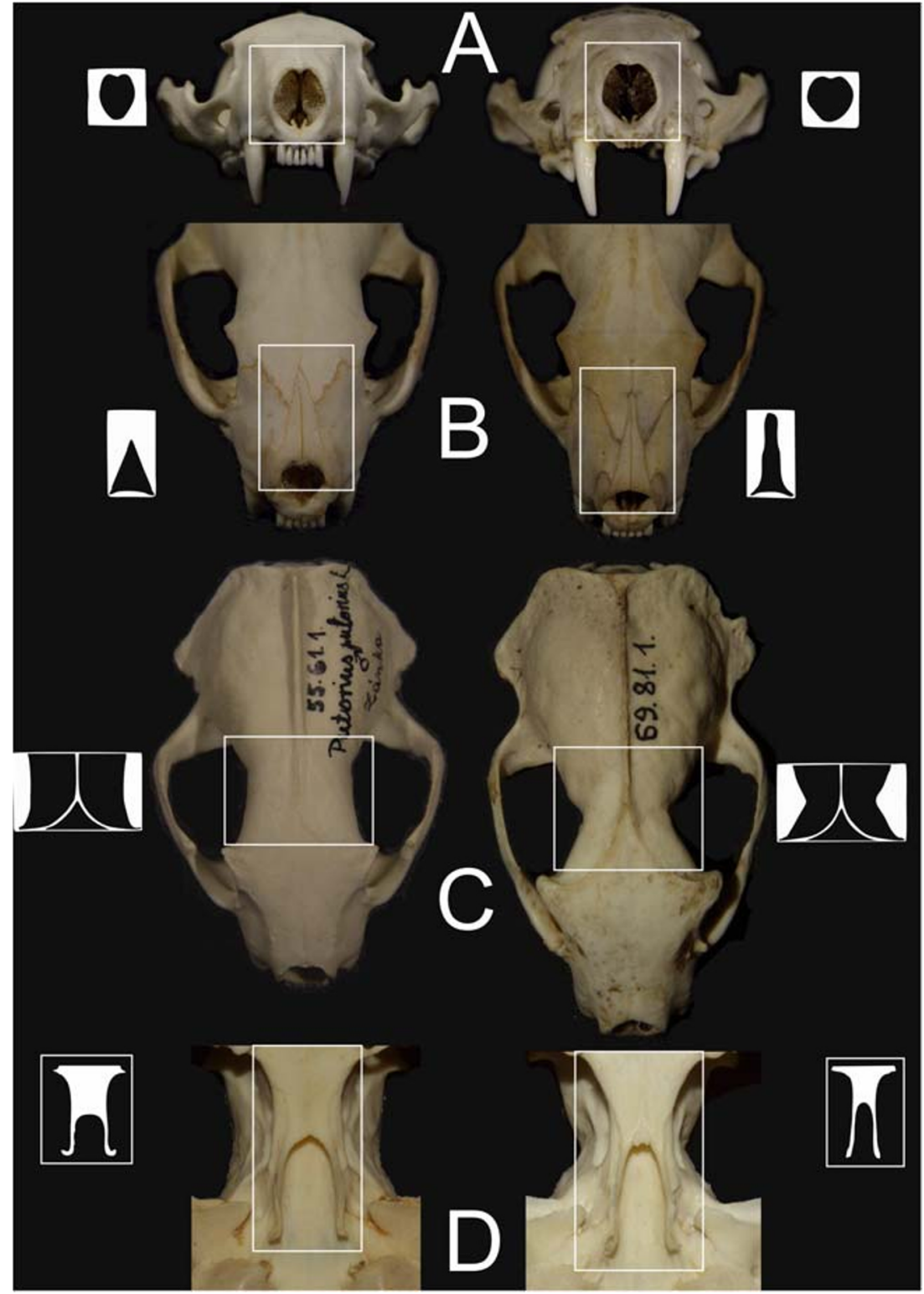

two species showed a remarkable differentiation, especially in the presence of a relatively distant outgroup. Within

Table 2 Frequency of individuals (in percentage of sample size) with atypical external phenotypic characteristics for species-specific characters ' $A$ ' to ' $D$ ' as defined above (see Material and methods)

\begin{tabular}{llllll}
\hline$\#$ & Group & A & B & C & D \\
\hline 1 & MP ALLO & 0 & 0 & 0 & 0 \\
2 & MP SYM & 4.8 & 3.2 & 1.6 & 1.6 \\
$2 \mathrm{a}$ & MP SYM UKR & 38.5 & 15.4 & 23.1 & 0 \\
3 & MEH SYM & 2.1 & 2.1 & 8.5 & 2.1 \\
4 & MEE SYM & 3.5 & 1.7 & 3.5 & 3.5 \\
5 & MEE ALLO & 0 & 0 & 0 & 0 \\
\hline
\end{tabular}

M. eversmanii, the two subspecies only partially overlapped. Obviously, $M$. eversmanii hungarica was closer to sympatric $M$. putorius than was any group of $M$. eversmanii eversmanii.

According to our jack-knife resampling, the rate of the correctly classified samples was $82.1 \%$ in our LDA. The discriminant scores applied to the identification of $M$. eversmanii and $M$. putorius mostly agreed with the determinations based on the assessment of museum catalogues, qualitative pelage and cranial characters (Table 4) as all but three individuals were correctly classified into their respective species groups. Those two intermediate-sized M. putorius (NMNHU 11619/2, Lozova, Ukraine; HNHM 4025.2, Tápiószele, Hungary) had species-specific phenotype, and it was also true for that single M. eversmanii eversmanii (NMNHU 102, Black Sea Reserve, Ukraine) (Tables 4) 
Table 3 Symmetrical pairwise squared Mahalanobis distance matrix based on craniometric traits between our analysed groups of European mustelids

\begin{tabular}{|c|c|c|c|c|c|c|c|c|}
\hline & MP SYM-f & MP ALLO & MEE ALLO & MEE SYM-m & MEE SYM-f & MEH SYM-m & MEH SYM-f & $\mathrm{NV}$ \\
\hline MP SYM-m & 9.3 & 4.2 & 16.8 & 15.1 & 17.6 & 7.9 & 12.8 & 38.2 \\
\hline MP SYM-f & & 6.0 & 18.8 & 18.8 & 11.0 & 15.1 & 5.9 & 32.1 \\
\hline MP ALLO & & & 20.5 & 18.9 & 15.4 & 13.7 & 13.2 & 41.6 \\
\hline MEE ALLO & & & & 4.6 & 8.8 & 4.6 & 8.9 & 44.4 \\
\hline MEE SYM-m & & & & & 6.8 & 6.0 & 11.0 & 44.4 \\
\hline MEE SYM-f & & & & & & 11.5 & 4.9 & 41.2 \\
\hline MEH SYM-m & & & & & & & 8.4 & 33.6 \\
\hline MEH SYM-f & & & & & & & & 27.8 \\
\hline
\end{tabular}

$f$ female, $m$ male

In LDA the first axis explained high proportion of variance $(48.8 \%)$ and had positive correlation coefficients with all but two variables (Table 2); this component was therefore interpreted as the main size factor. The second axis explained also a high proportion of variance (37.9\%), and this component was, therefore, interpreted as the postorbital width (measurement \#12). Actually, the samples of our focal species were separated partly along the second axis. The two polecat species, especially their allopatric populations, were mostly differentiated along the first canonical axis. The most relevant characters to the separation were the postorbital width (measurement \#12) and, to a lesser extent, the maxillary tooth-row length (6). The most important trait (widely used to distinguish between the species) is the shape of the postorbital region. Size ratios of these measurements between both species were 1.03 for maxillary tooth-row length (measurement \#6) and 1.11 for postorbital width (measurement \#12). The M. eversmanii hungarica population, and also the outgroup $N$. vison, were mostly differentiated along the second canonical axis, whose coefficients vector indicate a relevant influence of the zygomatic width (\#10) and the mastoid width (\#11). We repeated the LDA without the outgroup (results

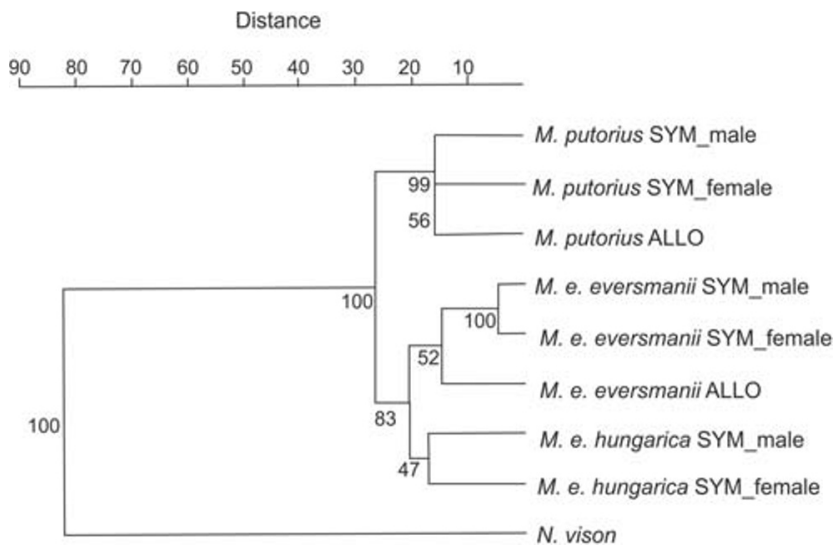

Fig. 3 UPGMA dendrogram derived from Mahalanobis D2distances among groups, including Neovison vison as outgroup. Numbers on nodes are bootstrap values (1000 replicates) shown and included as a Supplementary Fig. S2), and in this test, the characters 1, 10, 19 and 20 had the highest discriminative power. Independent $t$-tests showed that characters 1,19 and 20 in male $M$. eversmanii hungarica were significantly higher than those in male $M$. eversmanii eversmanii $(t=$ $19.995, p=0.032$; and $t=18.850, p<0.001$, respectively); however, the test did not reveal significant differences for females $(p>0.05) . T$-test with the same characters of $M$. putorius and $M$. eversmanii hungarica showed a significant difference only in character \#19 $(t=2.78, p=0.007)$ (Fig. $5)$.

\section{Congruence between size and phenotype}

Hybrids are not always intermediate in morphology between parental types; therefore, discrete phenotypic characters were given preference in assigning hybrids when discrepancies occurred. All specimens in allopatric populations displayed a species-specific phenotype - their size was congruent with the phenotype. However, this was not evident in sympatric populations where numerous atypical specimens were detected.

Of the $11 \mathrm{M}$. putorius samples collected in Ukraine, only five were undamaged and therefore suitable to record measurements. Two of those five Ukrainian M. putorius specimens exhibited a mosaic of character states (Table 5), but in the LDA, they were, indeed, unambiguously placed within the putorius group (see Fig. 4). Furthermore, only half of the unmeasured Ukrainian putorius showed the species-specific characteristics; the others displayed a mixture of characteristics of $M$. eversmanii and M. putorius.

Regarding M. eversmanii collected in Ukraine, two specimens had putorius-like phenotype (NMNHU 5211.3 Striltsivskyi Steppe Reserve, Luhansk Region; NMNHU 1658.99 Black Sea Reserve). This latter one was measured and the LDA supported its classification as M. eversmanii. NMNHU 5211.3 was not measured; however, it was collected in a steppe region of Eastern Ukraine where the occurrence of 


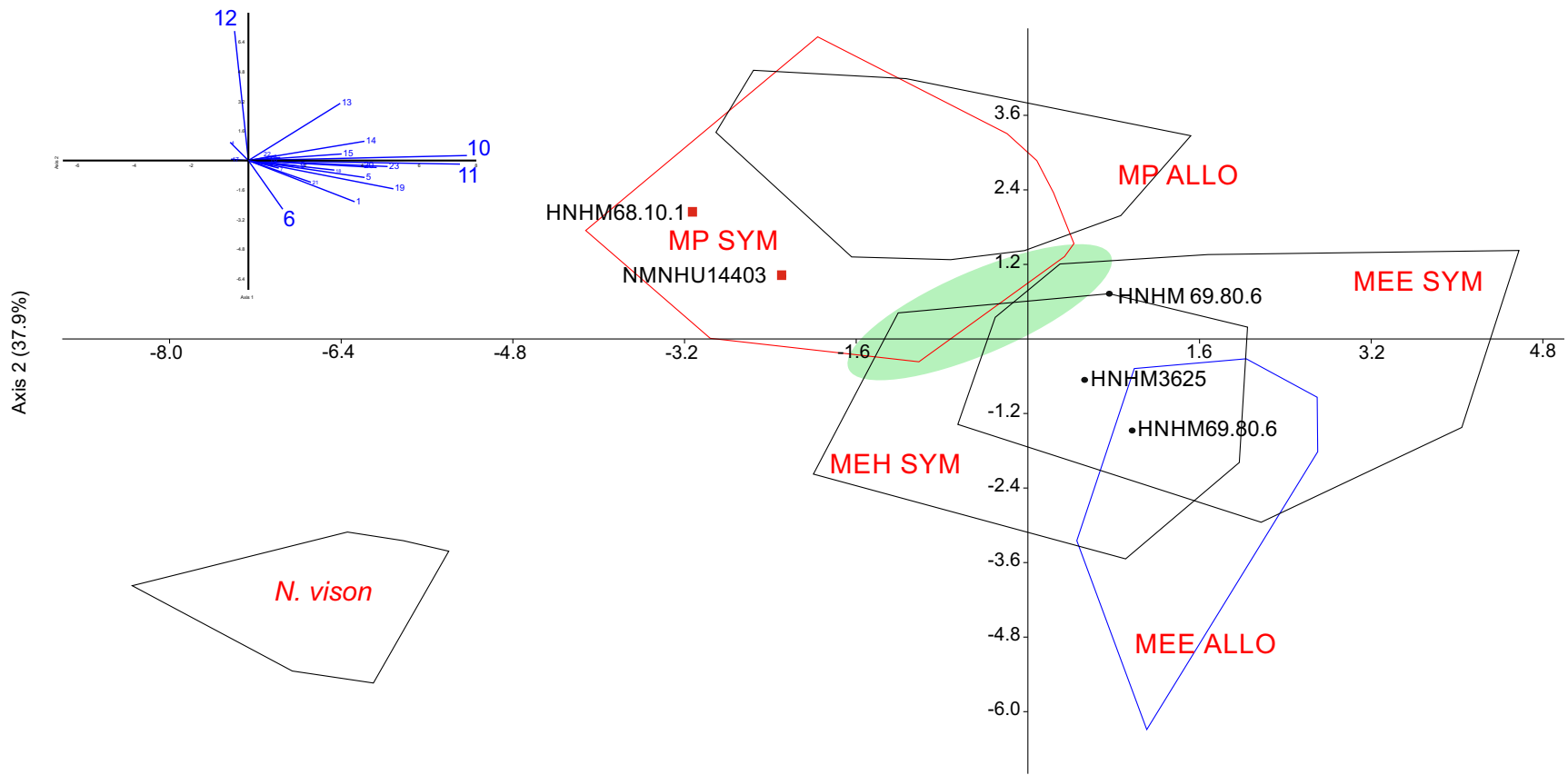

Axis $1(48.8 \%)$

Fig. 4 Projection of analysed specimens of mustelids in the morphological space as described along the first two axes of a linear discriminant analysis. Percentage of variance explained by the axes are in parentheses. Convex hulls show the dispersion of specimens within each group; for abbreviation, see Table 1. The overlaps between sample groups of the two species are highlighted. The individually displayed specimens represent samples which could be classified to the other

M. putorius is highly improbable; moreover, numerous other $M$. eversmanii individuals with species-specific phenotype and size originate from this (typical) habitat.

Morphological evidence (discrete characters) for hybridisation between $M$. putorius and $M$. eversmanii hungarica was found in a single $M$. putorius specimen

Fig. 5 Box plot of data underlying the independent $t$-tests for the measurements of male individuals: \#1, condylobasal length (CbL); \#19, total length of the mandible (ML); and \#20, length between the angular process and infradentale (AL)

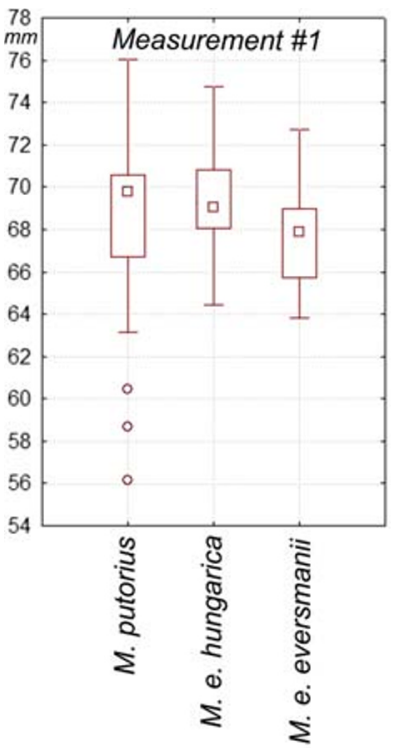

species based on their external craniological characteristics as defined in Table 2. Two M. putorius samples (red squares) exhibited eversmanii-like phenotype, whereas the black dots represent samples of $M$. eversmanii with putorius-like appearance; however, by their measurements and by the LDA, all these three samples were classified to the other species. Character vectors show relative contribution of the most important linear measurements

(HNHM 68.10.1.; Szabadszállás, Hungary; see Table 5). It had a pure putorius-like coat pattern, but the skull was strikingly characteristic of $M$. eversmanii. In the LDA, it was unambiguously placed within the putorius group (see Fig. 4). Among the $M$. eversmanii hungarica specimens, four samples exhibited a mosaic of discrete characters of the two species

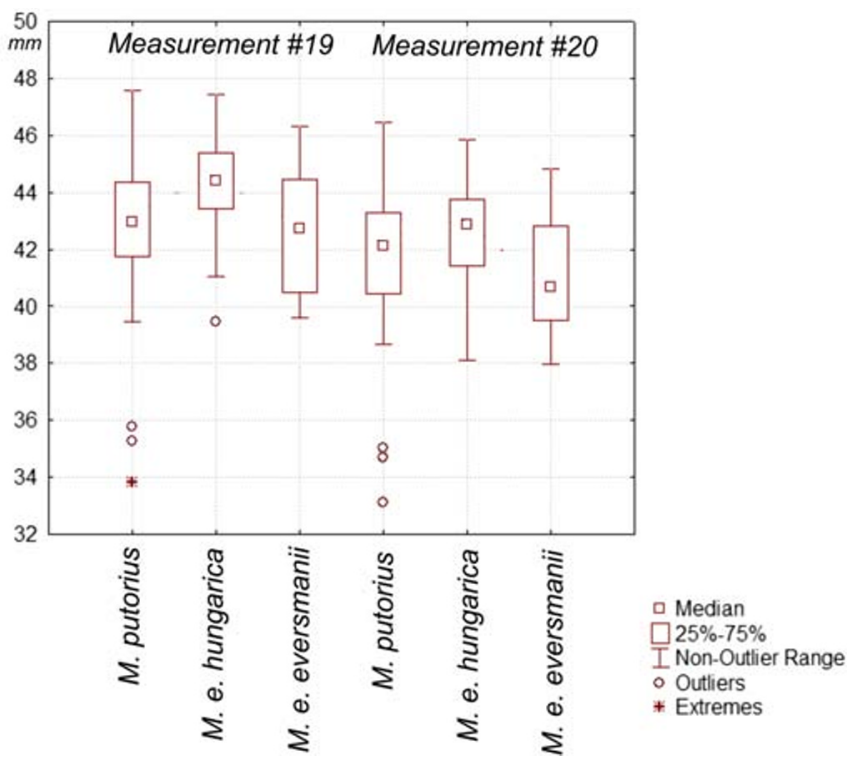


Table 4 Results of the discriminant analysis when clustering the sampled Mustela populations into eight groups + $N$. vison as outgroup

\begin{tabular}{|c|c|c|c|c|c|c|c|c|c|}
\hline $\begin{array}{l}\text { Given } \\
\text { group/ } \\
\text { predicted }\end{array}$ & $\begin{array}{l}\text { MP } \\
\text { SYMm }\end{array}$ & $\begin{array}{l}\text { MP } \\
\text { SYMf }\end{array}$ & $\begin{array}{l}\text { MP } \\
\text { ALLO }\end{array}$ & $\begin{array}{l}\text { MEE. } \\
\text { ALLO }\end{array}$ & $\begin{array}{l}\text { MEE } \\
\text { SYMm }\end{array}$ & $\begin{array}{l}\text { MEE. } \\
\text { SYMf }\end{array}$ & $\begin{array}{l}\text { MEH } \\
\text { SYMm }\end{array}$ & $\begin{array}{l}\text { MEH } \\
\text { SYMf }\end{array}$ & N. vison \\
\hline MP SYMm & 23 & 2 & 0 & 0 & 0 & 0 & $1 *$ & $1^{*}$ & 0 \\
\hline MP SYMf & 0 & 14 & 1 & 0 & 0 & 0 & 0 & 0 & 0 \\
\hline MP ALLO & 3 & 2 & 20 & 0 & 0 & 0 & 0 & 0 & 0 \\
\hline MEE ALLO & 0 & 0 & 0 & 6 & 1 & 1 & 1 & 1 & 0 \\
\hline $\begin{array}{l}\text { MEE } \\
\text { SYMm }\end{array}$ & $1 *$ & 0 & 0 & 6 & 25 & 1 & 3 & 0 & 0 \\
\hline MEE SYMf & 0 & 0 & 0 & 1 & 3 & 17 & 0 & 0 & 0 \\
\hline $\begin{array}{l}\text { MEH } \\
\text { SYMm }\end{array}$ & 0 & 0 & 0 & 3 & 0 & 0 & 30 & 1 & 0 \\
\hline MEH SYMf & 0 & 0 & 0 & 1 & 0 & 1 & 0 & 15 & 0 \\
\hline N. vison & 0 & 0 & 0 & 0 & 0 & 0 & 0 & 0 & 11 \\
\hline Total & 27 & 18 & 21 & 17 & 29 & 20 & 35 & 18 & 11 \\
\hline
\end{tabular}

Asterisk indicates incorrectly assigned individuals. Confusion matrix: column, predicted group; rows, given group

(HNHM 69.80.5. and HNHM 69.80.6. (Balmazújváros, Hungary), HNHM 3625 and HNHM 3626 (Tolna and BAZ Counties, Hungary). Three of them were measured and the LDA supported their classification as M. eversmanii.

We examined the congruence of size and phenotype from the other directions as well: two intermediate-sized M. putorius (NMNHU 11619/2, Lozova, Kharkiv Region, Ukraine, were incorrectly determined by the LDA; NMNHU $11623 / 6$ Oleshky, Kherson Region) and four M. eversmanii samples (HNHM 69.80.4, HNHM 4027, HNHM 3665, HNHM 67.141.4) located in overlapping morphological space of LDA had species-specific phenotype. The specimens NMNHU 102 and $4025 / 2$ marked by LDA as incorrectly determined individuals must be also listed here. These specimens designated the zone of intermediate-sized specimens (Fig. 4).

\section{Discussion}

The two closely related Palaearctic species of polecats, Mustela putorius and M. eversmanii, resemble each other morphologically, although M. putorius has a generally dark brown dorsal fur and tail, whereas the coat of $M$. eversmanii is light yellowish with contrasting dark limbs (Wolsan 1993b). Compared to M. putorius, M. eversmanii is larger in size and has a more robust skull (Heptner et al. 1967). The morphological differences between the two species could be related to different habitat preferences and diet (Heptner 1964). M. eversmanii occupies open fields such as grassland and cropfields, whereas M. putorius tends to occupy sparse lowland forests, shrubby meadows often in close proximity to water and smaller human settlements (Lariviere and Jennings 2009). In Hungary, they may
Table 5 Details of morphological hybrid polecat samples from Hungary, Ukraine and Russia, indicating their taxonomic affiliation based on museum labels, the classification by discriminant (LDA) scores and coding of discrete morphological characters

\begin{tabular}{|c|c|c|c|c|c|c|c|c|}
\hline ID by label & Sex & Coll. Num. & A & B & $\mathrm{C}$ & $\mathrm{D}$ & LDA scores & Locality \\
\hline MEE & $\mathrm{f}$ & HNHM 3535/02 & $\mathrm{p}$ & $\mathrm{p}$ & e & $\mathrm{e}$ & 0.9 & Voronezh Region, RUS \\
\hline $\mathrm{MEH}$ & $\mathrm{m}$ & HNHM 3625 & $\mathrm{e}$ & $\mathrm{e}$ & $\mathrm{p}$ & $\mathrm{e}$ & -0.7 & Tolna County, HUN \\
\hline $\mathrm{MEH}$ & $\mathrm{m}$ & HNHM 3626 & $\mathrm{e}$ & $\mathrm{e}$ & $\mathrm{p}$ & $\mathrm{e}$ & - & BAZ County, HUN \\
\hline MEH & & HNHM 69.80.6. & $\mathrm{e}$ & $\mathrm{e}$ & $\mathrm{p}$ & $\mathrm{e}$ & 0.3 & Balmazújváros, HUN \\
\hline MEH & & HNHM 69.80.5. & $\mathrm{e}$ & $\mathrm{e}$ & $\mathrm{p}$ & $\mathrm{e}$ & 1.1 & Balmazújváros, HUN \\
\hline MP & $\mathrm{m}$ & HNHM 68.10.1. & $\mathrm{e}$ & $\mathrm{e}$ & $\mathrm{p}$ & $\mathrm{e}$ & -2.9 & Szabadszállás, HUN \\
\hline MEE & $\mathrm{f}$ & NMNHU 5211.3 & $\mathrm{p}$ & $\mathrm{e}$ & $\mathrm{p}$ & $\mathrm{p}$ & 0.8 & Striltsivskyi Steppe, UKR \\
\hline MEE & $\mathrm{f}$ & NMNHU 1658.99 & $\mathrm{p}$ & $\mathrm{p}$ & $\mathrm{p}$ & $\mathrm{p}$ & 0.9 & Black Sea Reserve, UKR \\
\hline MP & $\mathrm{m}$ & NMNHU 14317 & $\mathrm{p}$ & $\mathrm{e}$ & $\mathrm{e}$ & $\mathrm{p}$ & - & Harasimivka, Luhansk, UKR \\
\hline MP & & NMNHU 5202 & $\mathrm{e}$ & $\mathrm{p}$ & $\mathrm{e}$ & $\mathrm{p}$ & - & Rudnivka, Sumy, UKR \\
\hline MP & $\mathrm{m}$ & NMNHU 11622 & $\mathrm{e}$ & $\mathrm{e}$ & $\mathrm{p}$ & $\mathrm{p}$ & -1.4 & Sumy, UKR \\
\hline MP & $\mathrm{f}$ & NMNHU 14403 & e & $\mathrm{p}$ & $\mathrm{e}$ & $\mathrm{p}$ & -2.7 & Zaporizhia, UKR \\
\hline
\end{tabular}

State 'e' refers to M. eversmanii and state 'p' to M. putorius. Specimens are listed if character 'C' or at least two other characters were atypical 
occasionally coexist in lowlands around settlements where the common hamster (Cricetus cricetus) is frequent (own unpublished data). In Western Europe, M. putorius showed a high level of specialization in capturing anurans (Hammershøj et al. 2004; Weber 1989); the diet of the steppe polecat predominantly consists of larger steppe rodents such as sciurids (marmots and ground squirrels), hamsters and pikas (Heptner et al. 1967; Ternovsky 1977). However, in Hungary, where the two species live in sympatry, their diet composition do not differ significantly on the basis of the main food items, and no frog predation was observed in Hungarian samples of M. putorius (Lanszki and Heltai 2007).

In the present study, based on a representative sample set of specimens from sympatric and non-sympatric populations of both species, we found clear size differences - specifically in the postorbital width and the maxillary tooth-row lengthbetween the examined species and subspecies. UPGMA and LDA both show two main species clusters, and the M. eversmanii were also divided into separate clusters. The morphometric analysis of the geographical variation in polecats revealed a complex picture. Similar to other widely distributed mustelids and wild felids, polecats varied markedly in body size and skull characteristics, and males showed a more considerable variation in size and form than females, probably influenced by sexual selection, social organization (sex-biased dispersal), size and availability of prey (Lariviere and Jennings 2009; Mazák 2010). As our multivariate analyses indicated, the variation in skull morphology of males is generally greater among populations and showed a stronger differentiation between geographical populations than females (Table 3).

Despite an overlap in morphological space, statistical analysis indicated significant differences in size between the two studied subspecies of the steppe polecat. M. eversmanii hungarica represents the westernmost population of the species with almost total spatial overlap with M. putorius, although the separation by habitat preference might be substantial. Our morphometric analysis indicate characteristics that usually represents a valid taxon, morphologically characterized by larger cranial sizes (see measurements \#1, 19 and 20), moreover, according to Wolsan (1993a) by the frequency of two-rooted P2 ( $\geq 50 \%$ in M. eversmanii hungarica) and the size of M1, which is larger in hungarica. The morphological divergence could possibly be due to an early isolation of a small population, or as a consequence of a bottleneck or ancient hybridisation between M. putorius and M. eversmanii. Indeed, M. eversmanii hungarica situated apparently between $M$. putorius and allopatric M. eversmanii groups, which could be an indication of ancient hybridisation as it is known that such hybridisation also leads to a higher degree of genetic similarity (and by extension morphological similarity) (Arnold 1997). The lack of gene flow between eversmanii populations isolated by the Carpathians and genetic drive may have also played a role in the rapid divergence, probably amplified by adaptations to local conditions and prey sources. As a conclusion, following Éhik (1928) and Wolsan (1993b), we suggest maintaining the subspecies status of $M$. eversmanii hungarica, but this taxonomic view should be also confirmed by appropriate molecular markers (e.g. microsatellites and RAD-seq). Additionally, we need to check if the morphological results found in this study can simply be result of a geographic gradient that aligns east-to-west along the evolutionary history of subgenus Putorius. For such analyses, the abovementioned molecular markers are highly suitable.

High number of intermediate-sized individuals may also indicate hybridisation (Benedict 1999; Gligor et al. 2009; Lehtinen et al. 2016), and in our study, the individuals of sympatric populations were located closer to the 'intermediate zone' of the morphometric space (Fig. 4). However, detecting hybrids is not possible only by the size of the individuals. Delimitation of the four discrete morphological characters used in this study was found to be unequivocal in our analysis (by the approximate absence of the characters typical of the other species in the allopatric populations) and allowed us to disregard intraspecific variability and focus on mosaics of character states truly diagnostic of morphological hybrids. The conflict between size and phenotype could be a strong indication of hybridisation, so we match the size and phenotype in several putative hybrids. The morphological examination of $111 \mathrm{M}$. putorius and $150 M$. eversmanii specimens and the use of LDA yielded concordant results and allowed the identification of 12 morphological hybrids in the sympatric populations. However, this is not necessarily mirrors the exact frequency of hybrids but rather indicates the potential presence and magnitude of hybridisation. Mixture of morphological characters is sometimes ambiguous because hybrids can express a great variety of possible parental phenotypes. In such cases, correct hybrid detection may be seriously hindered, and hybridisation rates might be underestimated (Rhymer and Simberloff 1996). On the other hand, not all morphological variation has a genetic basis, and the amount of morphological variation within and among populations is often greater than is actually recognized. Hybrids sometimes express a mosaic of parental phenotypes or display novel phenotypes (Ackermann et al. 2006), and individuals from hybrid swarms that contain most of their genes from one of the parental taxa are often morphologically indistinguishable from that parental taxon (Allendorf et al. 2001). A study on dingo (Canis familiaris dingo) showed that hybrids and pure dingos greatly overlap morphologically, and these intraspecific hybrids cannot be reliably distinguished by craniometrics (Parr et al. 2016). In case of Lepus timidus and the L. europaeus, introgressed hares could not be identified by skull shape analysis; however, introgressed hares might exhibit significantly higher inter-individual variability for certain metric variables than non-introgressed individuals (Suchentrunk et al. 2005).

Wolsan (1993b) also studied sympatric and allopatric populations of M. putorius and M. eversmanii, and a number of specimens showing a combination of species-specific 
characters were nearly twice in sympatric populations compared to the allopatric ones that he regarded as a clear indication of hybridisation. In our study, the rate of atypical specimens (putative hybrids) was also higher in sympatric populations, especially among the Ukrainian M. putorius samples. Molecular analyses definitely would provide a deeper insight into this phenomenon, but this is seriously hindered by the lack of recently obtained genetic material from the Eastern European region. M. eversmanii has almost disappeared from the Ukrainian fauna due to loss of its habitat and its prey (Selyunina 2017); the latest known museum specimen was collected in 1999 in Kherson Region, while the latest observations of live animals were reported in 2007 from Luhansk Oblast (Cherednichenko 2008).Certainly, polecats deserve much more attention from the evolution and conservation biological scientist and wildlife experts.

Acknowledgements We are very grateful to Darrin Lunde (Smithsonian National Museum of Natural History) and Manuel Ruedi (Muséum d'histoire naturelle) for supplying samples. We also thank two anonymous reviewers for their comments and suggestions.

Code availability All software are cited in the manuscript.

Authors' contributions All authors contributed to the study conception and design. Material preparation, data collection and analysis were performed by Tamás Cserkész, Csaba Kiss and Zoltán Barkaszi. The first draft of the manuscript was written by Tamás Cserkész, and all authors commented on previous versions of the manuscript. All authors read and approved the final manuscript.

Funding Open access funding provided by Hungarian Natural History Museum.

Data availability The datasets generated during and/or analysed during the current study are available from the corresponding author on reasonable request.

\section{Compliance with ethical standards}

Conflict of interest The authors declare that they have no conflict of interest.

Ethics approval Not applicable.

Consent to participate All authors agreed to participate in this study and co-authorship.

Consent for publication All authors agreed with the content and that all gave explicit consent to submit.

Open Access This article is licensed under a Creative Commons Attribution 4.0 International License, which permits use, sharing, adaptation, distribution and reproduction in any medium or format, as long as you give appropriate credit to the original author(s) and the source, provide a link to the Creative Commons licence, and indicate if changes were made. The images or other third party material in this article are included in the article's Creative Commons licence, unless indicated otherwise in a credit line to the material. If material is not included in the article's Creative Commons licence and your intended use is not permitted by statutory regulation or exceeds the permitted use, you will need to obtain permission directly from the copyright holder. To view a copy of this licence, visit http://creativecommons.org/licenses/by/4.0/.

\section{References}

Abbott R, Albach D, Ansell S, Arntzen JW, Baird SJE, Bierne N, Boughman J, Brelsford A, Buerkle CA, Buggs R, Butlin RK, Dieckmann U, Eroukhmanoff F, Grill A, Cahan SH, Hermansen JS, Hewitt G, Hudson AG, Jiggins C, Jones J, Keller B, Marczewski T, Mallet J, Martinez-Rodriguez P, Möst M, Mullen S, Nichols R, Nolte AW, Parisod C, Pfennig K, Rice AM, Ritchie MG, Seifert B, Smadja CM, Stelkens R, Szymura JM, Väinölä R, Wolf JBW, Zinner D (2013) Hybridization and speciation. J Evol Biol 26:229-246. https://doi.org/10.1111/j.1420-9101.2012.02599.x

Abramov AV (2000) A taxonomic review of the genus Mustela (Mammalia, Carnivora). Zoosyst Ross 8:357-364

Abramov AV, Puzachenko A (2009) Spatial variation of sexual dimorphism in the Siberian weasel Mustela sibirica (Mustelidae, Carnivora). Russian J Theriol 8:17-28

Abramov AV, Puzachenko A, Tumanov I (2016a) Morphological differentiation of the skull in two closely-related mustelid species (Carnivora: Mustelidae). Zool Stud 55:23. https://doi.org/10.6620/ ZS.2016.55-01

Abramov AV, Puzachenko A, Tumanov I (2016b) Morphological differentiation of the skull in two closely-related mustelid species (Carnivora: Mustelidae). Zool Stud 55:23. https://doi.org/10.6620/ ZS.2016.55-01

Ackermann RR, Rogers J, Cheverud JM (2006) Identifying the morphological signatures of hybridization in primate and human evolution. J Hum Evol 51:632-645. https://doi.org/10.1016/j.jhevol.2006.07.009

Allendorf FW, Leary RF, Spruell P, Wenburg JK (2001) The problems with hybrids: setting conservation guidelines. Trends Ecol Evol 16: 613-622. https://doi.org/10.1016/S0169-5347(01)02290-X

Anderson E (1977) Pleistocene Mustelidae (Mammalia, Carnivora) from Fairbanks, Alaska. Bull Mus Comp Zool 148:1-21

Anderson E, Forrest SC, Clark TW, Richardson L (1986) Paleobiology, biogeography, and systematics of the black-footed ferret, Mustela nigripes (Audubon and Bachman), 1851. Great Basin Naturalist Memoirs 8:3

Ansorge H, Suchentrunk F (2001) Aging steppe polecats (Mustela eversmanni) and polecats (Mustela putorius) by canine cementum layers and skull characters. Wiss Mitt Niederösterr Landesmuseum 14:79-106

Arnold ML (1997) Natural hybridization and evolution. Oxford University Press, Oxford

Benedict RA (1999) Morphological and mitochondrial DNA variation in a hybrid zone between short-tailed shrews (Blarina) in Nebraska. J Mammal 80:112-134. https://doi.org/10.2307/1383213

Blandford PRS (1987) Biology of the polecat Mustela putorius: a literature review. Mammal Rev 17:155-198. https://doi.org/10.1111/j. 1365-2907.1987.tb00282.x

Buchalczyk T, Ruprecht AL (1977) Skull variability of Mustela putorius Linnaeus, 1758. Acta Theriol 22:87-120

Cabria MT et al (2011) Bayesian analysis of hybridization and introgression between the endangered european mink (Mustela lutreola) and the polecat (Mustela putorius). Mol Ecol 20:1176-1190. https://doi. org/10.1111/j.1365-294X.2010.04988.x

Cherednichenko V (2008) Role of the marmot in steppe biocenose of north-eastern Ukraine. Proceedings of the Theriological School 9: $279-280$ 
Croose E, Duckworth JW, Ruette S, Skumatov Dmitry V, Kolesnikov Vyacheslav V, Saveljev Alexander P (2018) A review of the status of the Western polecat Mustela putorius: a neglected and declining species? Mammalia 82:550-564. https://doi.org/10.1515/ mammalia-2017-0092

Davison A, Birks J, Griffiths H, Kitchener A, Biggins D, Butlin R (1999) Hybridization and the phylogenetic relationship between polecats and domestic ferrets in Britain. Biol Conserv 87:155-161. https:// doi.org/10.1016/S0006-3207(98)00067-6

De Marinis A (1995) Craniometric variability of polecat Mustela putorius L. 1758 from north-central Italy. Hystrix 7:57-68. https://doi.org/10. 4404/hystrix-7.1-2-4053

Éhik G (1928) A mezei görény (Mustela eversmanni Less.) hazánkban. Annls hist-nat Mus natn hung 25:1-38

Gligor M, Ganzhorn J, Rakotondravony D, Ramilijaona O, Razafimahatratra E, Zischler H, Hapke A (2009) Hybridization between mouse lemurs in an ecological transition zone in southern Madagascar. Mol Ecol 18:520-533. https://doi.org/10.1111/j. 1365-294X.2008.04040.x

Hammer Ø, Harper DAT, Ryan PD (2001) PAST: paleontological statistics software package for education and data analysis., 3.02 edn.,

Hammershøj M, Thomsen EA, Madsen AB (2004) Diet of free-ranging American mink and European polecat in Denmark. Acta Theriol 49: 337-347. https://doi.org/10.1007/BF03192532

Heptner V (1964) Über die morphologischen und geographischen Beziehungen zwischen Mustela putorius und Mustela eversmanii. Z Saugetierkd 29:321-330

Heptner V, Naumov N, Yurgenson P, Sludsky A, Chirkova A, Bannikov A (1967) Mammals of the USSR vol 2. Sirenia and Carnivora, vol part 1. Vysshaya Shkola, Moscow

Kurose N, Abramov AV, Masuda R (2008) Molecular phylogeny and taxonomy of the genus Mustela (Mustelidae, Carnivora), inferred from mitochondrial DNA sequences: new perspectives on phylogenetic status of the back-striped weasel and American mink. Mamm Study 33:25-33. https://doi.org/10.3106/1348-6160(2008)33[25:MPATOT]2.0.CO;2

Lanszki J, Heltai M (2007) Diet of the European polecat and the steppe polecat in Hungary. Mamm Biol 72:49-53. https://doi.org/10.1016/ j.mambio.2006.07.002

Lariviere S, Jennings A (2009) Family Mustelidae. In: Wilson D, Mittermeier R (eds) Handbook of the mammals of the world, Vol. 1 Carnivores. Lynx Edicions, Barcelona, pp 564-656

Lawes I, Andrews P (1987) Variation of the ferret skull (Mustela putorius furo L.) in relation to stereotaxic landmarks. J Anat 154:157-171

Lehtinen RM, Steratore AF, Eyre MM, Cassagnol ES, Stern ML, Edgington HA (2016) Identification of widespread hybridization between two terrestrial salamanders using morphology, coloration, and molecular markers. Copeia 104(132-139):138-139. https://doi. org/10.1643/CH-14-205

Maran T, Skumatov D, Abramov A, Kranz A (2016) Mustela eversmanii. The IUCN red list of threatened species 2016: e. T29679A45203762

Matchett R (2016) Black-footed ferret restoration; history, challenges and current status. Intermt J Sci 22:94

Mazák JH (2010) Geographical variation and phylogenetics of modern lions based on craniometric data. J Zool 281:194-209. https://doi. org/10.1111/j.1469-7998.2010.00694.x

Nowak J, Paradiso JL (1983) Walker's mammals of the world, vol 1-2, 4th edition edn. Johns Hopkins University press, Baltimore

O'Brien SJ, Martenson JS, Eichelberger MA, Thorne ET, Wright F, Bogan MA, Anderson SH (1989) Genetic variation and molecular systematics of the black-footed ferret. In: Seal US (ed) Conservation biology and the black-footed ferret. Yale University Press, London, pp 21-34. https://doi.org/10.2307/j.ctt2250xjr.7

Parr WC, Wilson LA, Wroe S, Colman NJ, Crowther MS, Letnic M (2016) Cranial shape and the modularity of hybridization in dingoes and dogs; hybridization does not spell the end for native morphology. Evol Biol 43:171-187. https://doi.org/10.1007/s11692-016-9371-x
Pocock R (1932) Ferrets and polecats. Scott Nat 196:97-108

Polushina NA (1958) Changes in distribution of some representatives of the family of Mustelids in the west of Ukraine. In: Problems of Land Zoogeography 129-137

Rees DJ, Dioli M, Kirkendall LR (2003) Molecules and morphology: evidence for cryptic hybridization in African Hyalomma (Acari: Ixodidae). Mol Phylogenet Evol 27:131-142. https://doi.org/10. 1016/S1055-7903(02)00374-3

Rhymer JM, Simberloff D (1996) Extinction by hybridization and introgression. Annu Rev Ecol Evol Syst 27:83-109. https://doi.org/10. 1146/annurev.ecolsys.27.1.83

Sato JJ, Hosoda T, Wolsan M, Tsuchiya K, Yamamoto M, Suzuki H (2003) Phylogenetic relationships and divergence times among mustelids (Mammalia: Carnivora) based on nucleotide sequences of the nuclear interphotoreceptor retinoid binding protein and mitochondrial cytochrome b genes. Zool Sci 20:243-264. https://doi.org/ 10.2108/zsj.20.243

Sato JJ, Wolsan M, Prevosti FJ, D’Elía G, Begg C, Begg K, Hosoda T, Campbell KL, Suzuki H (2012) Evolutionary and biogeographic history of weasel-like carnivorans (Musteloidea). Mol Phylogenet Evol 63:745-757. https://doi.org/10.1016/j.ympev.2012.02.025

Selyunina ZV (2017) Review of the family Mustelidae in the region of the Black Sea biosphere reserve. Proceedings of the Theriological School 15:49-57. https://doi.org/10.15407/ptt2017.15.049

Skumatov D et al (2016) Mustela putorius. The IUCN red list of threatened species e.T41658A45214384

STATSOFT Inc (2007) Statistica. Data analysis software system. Version 8 for windows. Tulsa, Oklahoma, USA

Suchentrunk F, Mamuris Z, Stamatis C, Ben Slimen H, Hackländer K, Haerer G, Giacometti M (2005) Introgressive hybridization in wild living mountain hares (L. timidus varronis) and brown hares (L. europaeus) and morphological consequences. Mamm Biol 70:39-40

Tatarinov KA (1956) Mammals of western regions of Ukraine. Academy of Sciences of UkrSSR Publishing, Kiev

Ternovsky D (1977) Biology of mustelids (Mustelidae). Nauka Publishing House, Novosibirsk, Soviet Union

Ternovsky D, Ternovskaya YG (1994) Ekologiya kunitseobraznykh (ecology of mustelids). Nauka, Novosibirsk

Ujhelyi P (1994) A magyarországi vadonélő emlősállatok határozója. In: Magyar Madártani Egyesület könyvtára. Magyar Madártani Egyesület, Budapest

Weber D (1989) Foraging in polecats (Mustela putorius L.) of Switzerland: the case of a specialist anuran predator. Z Saugetierkd 54:377-392

Wilson DE, Reeder DAM (2005) Mammal species of the world: a taxonomic and geographic reference, vol 12. k. Johns Hopkins University Press, Baltimore

Wolsan M (1993a) Mustela eversmanni Lesson, 1827—Steppeniltis. In: Neithammer J, Krapp F (eds) Handbuch der Säugetiere Europas, Bd. 5. Raubsäuger, vol 5. Raubsäuger (Teil II.), vol 2. Aula-Verlag, Wiesbaden, pp. 770-816

Wolsan M (1993b) Mustela putorius Linnaeus, 1758-Waldiltis, Europäischer Iltis, Iltis. In: Niethammer J, Krapp F (eds) Handbuch der Säugetiere Europas, Bd. 5. Raubsäuger, vol 2, vol 2. AULA-Verlag, Wiesbaden, pp 699-769

Wolsan M, Sato JJ (2010) Effects of data incompleteness on the relative performance of parsimony and Bayesian approaches in a supermatrix phylogenetic reconstruction of Mustelidae and Procyonidae (Carnivora). Cladistics 26:168-194. https://doi.org/ 10.1111/j.1096-0031.2009.00281.x

Zagorodniuk IV (2011) Interspecies hybridization and factors of its formation in the east-European mammalian fauna. Stud Biol 5:173210

Publisher's note Springer Nature remains neutral with regard to jurisdictional claims in published maps and institutional affiliations. 